\title{
Financial Openness and Poverty Level: The Empirical Investigation in Nigeria
}

\author{
Oluwayemisi Kadijat ADELEKE \& Omowunmi Monisola AJEIGBE \\ Department of Economics, Redeemer's University, Ede, Osun State, Nigeria
}

\begin{abstract}
This study examined the effect of financial openness on poverty level in Nigeria from 1981 to 2018, using Autoregressive Distributed Lag (ARDL) technique. The study found that the lagged value of poverty has a positive and significant relationship with itself. This buttresses the point that poverty in the previous period's filters directly into the present period. Again, the study found that financial deepening has an inverse and significant effect on poverty, while financial openness was found to have a positive and significant impact on poverty. Finally, the lagged value of growth rate, investment, inflation and institutional quality has an inverse and significant effect on poverty.
\end{abstract}

JEL CLASSIFICATION: F65, I31, I38

\section{INTRODUCTION}

$\mathrm{T}$ he Nigerian financial system has gone through various reforms to improve financial sector efficiency, increase its economic growth, which will in-turn affect development issues positively. However, before the structural adjustment programme (SAP) was introduced in 1986, the Nigerian financial sector experienced rigidity in exchange rate and interest rate, sectoral allocation of bank credits and maximum level of bank credits available to the private sector. These attributes led to reduced direct investment in the financial system, inadequate funds, overvaluation of currency and a bearish economy. Thus, the period between 1959 and 1986 was seen as the period of banking regulation in Nigeria and financial repression.

However, after the introduction of structural adjustment programme (SAP) in 1986, the Nigerian financial system witnessed several reforms and financial liberalization measures were adopted, such as, financial openness, liberalised interest rate and exchange rate (Ogwuma, 1993; Ojo, 1993). Financial liberalization operates based on a market system and it encourages competition and also attracts investors both locally and internationally. The belief is that a financially liberalized sector will allow for mobilization of necessary funds for development and channeling of funds into the most efficient use in accordance with the McKinnon and Shaw (1973) argument. According to them, they criticized government policies which restricted and controlled financial markets and believed that it brings about low growth rates, which leads to increase in poverty rates.

Financial liberalization has two important dimensions; it can be characterized by opening the capital account and lifting restrictions on domestic financial system. Capital account liberalization policies allows corporations to borrow abroad, removing multiple exchange rate systems and other forms of capital controls while, domestic financial system liberalization is aimed at relaxing restrictions on credit allocation, foreign currency deposits, foreign equity ownership, repatriation of capital, dividends and interest incomes (Galindo et al, 2002). The liberalization/openness of financial systems brings about global linkages as it brings about cross border financial flows which lead to increase in economic growth and possible reduction in poverty through direct or indirect channels.

Financial openness is an important aspect of financial liberalization because it leads to integration in the financial market, which causes huge changes in a countries production pattern, strategies of doing business, which can be seen in the quantity and quality of international capital flows (Serdaroglu, 2015). It is of no doubt that financial openness is an important determinant of growth and development in any economy (Arestis and Caner; 2005, Adam; 2011). This is because higher degrees of countries openness mean more capital flow into the economy, and this leads to increase in savings, which could result to allocating capital to the most productive sectors in the economy, thereby leading to increase in national income and it could have a trickle-down effect on poverty reduction. Thus, we can infer that financial openness has a direct effect on growth and an indirect effect on poverty. The direct effect is experienced when growth in an economy is directed towards the sectors or regions where we have the poor and Its provision of factor services. Although, this channel appears more effective in poverty reduction, the risks faced by the poor is very high when there is a downturn in the economy. The indirect effects could be seen when government adopt redistributive policies like taxes and transfer, and use the funds realized to expand investment of the poor and safety nets for the poor.

A financially open economy can transmit its effect to the economy through various channels. One of the channels is that the country would enjoy free flow of capital, when this occurs, the cost of borrowing will reduce and investment would be stimulated. A high level of investment brings about a better economy, which increases the national income and could lead to reduction in poverty in the country. Also, another way in which a financially open economy is advantageous to a country is that the domestic financial institutions would be put to increased competition and would offer better services in the economy. Financial openness also brings about improved welfare, because countries would enjoy free flow of capital amongst themselves and also share 
risk but the problem is that it is highly volatile. This is because any sudden reversal of funds would have adverse effects, a typical example is the global recession in 2017 which affected the Nigerian economy greatly and increased poverty rates. Lastly, the transmission channel would also have significant impact on the economy if the institutions are strong and sound. This means that the economy must have strong and sound infrastructure in place to be able to achieve the goal of reducing poverty.

The work of McKinnon and Shaw (1973) criticized government policies and concluded that one of the significant reasons for low growth rate in many developing countries was as a result of restriction and control of the financial markets. This notion has been supported by several economists and thus in support of financial openness. However, others are of the opinion that financial openness has short term costs which has adverse effects on poor countries. This implies that increased inflow of capital into developing countries and the abrupt reversal have been led to instability in the financial sector, economic crises and significant increase in poverty, especially in countries with inefficient debt management system and a poorly regulated domestic financial system (Agenor, 2002). Several studies have been done on the relationship between financial openness and economic growth, but few studies have focused on its effect on poverty and consensus has not been reached. Some studies find a positive relationship (Agenor, 2002: Adam, 2011: Dhrifi and Maktouf, 2013; Serdaroglu, 2015), and they are of the opinion that financial openness plays important role in the development of a country, as it leads to improved welfare and increased standard of living which reduces poverty. However, some studies found a negative relationship and they were of the opinion that uncontrolled capital flows may lead to reduction in business activities where there is inefficient institutional quality and financial depth (Figini and Santarrelli, 2013). This low growth rates experienced in developing countries have been linked to government restrictions and control of the financial market and overtime in developed economy, financial openness has led to more efficient investment, which increased growth and reduced poverty.

Financial openness is seen as one of the pro-growth policies, because it has been identified as a potential source of growth in a country, which can reduce poverty. Prior to the period of financial liberalization, capital inflows into the Nigerian economy was at its bearest minimum of $0.3 \%$, but after the liberalization of the financial sector, the capital inflows increased tremendously from $0.6 \%$ in 1985 to $2 \%$ in 1987 , $8 \%, 10 \%$ and $13 \%$ in 1989,1993 and 1994 , but by the end of the military regime it has reduced to $4 \%$ in 1998 and started increasing from the year 2000 from $7 \%, 10 \%$ and $13 \%$ in 2002, 2005 and 2009 respectively. The capital inflow experienced a decrease in 2015 as the Nigerian economy experienced a recession during that period but it's on the increase in recent times. Despite, the policy of financial liberalization in the Nigerian economy, the poverty rate has been on a steady increase from $21.5 \%, 27.4 \%, 31.1 \%, 21.9 \%$ and $21.8 \%$ from 1981 till date, meanwhile, financial openness has been used in other developed economy to reduce poverty.

The issue of poverty reduction is one of the key macroeconomic objectives of the International Monetary Fund (IMF) and the World Bank, and they have made it one of their development assistance programs and to eradicate or reduce poverty. In order to achieve this objective, several policies or reforms have been put in place, and priorities have been given to pro-growth policies and countries who have experienced high growth rates and have managed to reduce poverty (Dhrifi, 2013). Despite the reforms made in the financial sector in the Nigerian economy, poverty rates have been seen to be increasing. Thus, the contributions of this paper are to examine the effect of financial openness on poverty reduction, to see if there is a directional relationship between financial openness and poverty reduction in Nigeria and lastly, to know if a countries financial openness has long run effect on poverty reduction in Nigeria. The paper is arranged in five sections. Introduction in section one while section two consists of related literature. The third section describes the method and section four and five which consists of empirical results and conclusion respectively.

\section{LITERATURE REVIEW}

The neoclassical theory has been seen to show the link between financial openness and poverty, because the theory posits that, a financially open economy increases savings which leads to distributing capital to the most productive sector. This increase in capital leads to increase in productivity, which brings about increase in income, thereby reducing poverty. This is seen as the trickle-down effect of growth reducing poverty by neo- classicals. Arestis et al (2005), added two channels linking financial openness and poverty. The first channel is the crises channel and this leads to changes in macroeconomic cycles, increase in volatility and vulnerability to financial crises. The second is the access to credit and financial services channel. Here, the poor are directly affected in the case of reversal of funds, as they will bear all the risks, this could lead to financial openness having adverse effect on poverty. Townsend (1979) believes that increased exposure to volatility leads to increased domestic interest rate (due to default risk), which in-turn lowers domestic output and increase in poverty.

Empirical studies have also affirmed the linkage between financial openness and poverty reduction. Although, little research has been done in the area, most studies focused on its effect on economic growth. Dandume and Malarvizhi (2014) examined the linkage among financial liberalization, economic growth and poverty reduction in Sub-Saharan African countries. Their findings show that economic growth has a positive effect in reducing poverty and financial liberalization has a positive effect on economic growth. However, the study indicates that financial liberalization has no significant effect in reducing poverty. Figini and Santarrelli (2006) studied the link between openness (trade and financial) and domestic poverty. The study found that financial openness 
leads to increase in relative poverty. This suggests that financial openness, policies targeted at reducing the size of the public intervention are found to increase relative poverty. Keho (2017) studied the the link among financial development, economic growth and poverty reduction in nine African countries using the ARDL bounds testing approach from 1970-2013. The study found a long run relationship among the variables in countries with in high economic growth. Also, financial deepening has a positive effect in reducing poverty in five African countries with the exclusion of Nigeria and, poverty reduction has a positive effect on economic growth in three countries with the inclusion of Nigeria. Furthermore, a bidirectional long run causal relationship does not exist for Nigeria in the link between financial openness and poverty.

Adam (2011) investigated financial openness induced growth on poverty in Ghana, studying whether financial liberalization benefits the poor. The study found a long run positive relationship between growth and financial liberalization and a positive but disproportionate relationship between economic growth and standard of living. Agenor (2002) examined the extent to which globalization affects the poor in low- and middle-income countries. Here, he used both the trade and financial openness indicators to describe the various channels through which globalization can occur using the globalization index and its effect on poverty. The study found the existence of a non monotonic laffer-type relationship between globalization and poverty. The study found that at low levels, globalization appears to hurt the poor, but beyond a certain threshold, it seems to reduce poverty. He concluded that globalization may hurt the poor not because it went too far, but rather because it did not go far enough.

Lassoued (2018) studied the relationship between financial liberalization, inflation and poverty using three developing countries, 19 low income countries, 47 middle income countries samples using the dynamic GMM panel. He saw the direct and indirect relationship between financial liberalization and poverty. The direct relationship is the McKinnon effect and the indirect relationship being through economic growth reducing poverty. The result shows that poverty is a persistent phenomenon, which implies that the present poverty levels is influenced by the past levels of poverty. Also, increase in financial liberalization was found to reduce poverty, which supports the conclusions reached by McKinnon.

Dhrifi and Maktouf (2013) investigated the issues relevant to the threshold effect of financial development on which financial liberalization changes sign using the dynamic GMM estimator. The result show that financial liberalization contributes to poverty reduction according to the level of domestic financial development. The result implies that even at a certain threshold of financial development, less financially liberalized economy is more likely to reduce their poverty rates. Okungbowa et al (2014) investigated the relationship between globalization and poverty rate in Nigeria using the cointegration and error correction method (ECM) and they found that an increase in openness brings about a decline in poverty rate in Nigeria. They found that domestic investment was significant and has a positive effect on poverty reduction; however, the current value of foreign direct investment had a negative and insignificant relationship to poverty.

Summarily, the review of literature on financial openness and poverty reduction show that the debate on the effects has not been settled, apart from it being scarcely researched and thus require further investigations. More so, previous empirical analyses have focused solely on economic growth and failed to consider the effects of a country's financial openness on its poverty level, especially in a country like Nigeria. These gaps remain the concern of this paper.

\section{METHODOLOGY}

\section{Model Specification}

The paper acknowledges that there are several other factors responsible for poverty reduction but financial openness is an important factor. Several researches have estimated the relationship between financial openness and poverty using Vector error correction mechanism (VECM), Autoregressive Distributed lag model (ARDL), Panel Ordinary least square, Sensitivity Analysis, Granger causality test and dynamic models such as the Generalized moments of methods (GMM) (see Agenor, 2002; Figini and Santarrelli, 2006; Adam, 2011; Ajide, 2015; Keho, 2017 and Lassoued, 2018). However, this study intends to examine the effects of financial openness on poverty level and to determine a long run relationship exist between the two variables using the Autoregressive distributed lag model (ARDL). This estimation technique, Autoregressive Distributed Lagged (ARDL) bound test was developed by Pesaran, Shin and Smith (2001), and can be applied irrespective of whether the variables are endogenous or integrated at order one or zero and even when the sample size is considered small.

Furthermore, the method commonly used in measuring financial openness is by building an index of capital account restrictions (reported in the IMFs Annual Report on Exchange Arrangements and Restrictions (AREARE)), however, the problem with this method is that it does not show the intensity of capital restrictions. According to (Agenor, 2002; Figini et al, 2006), financial openness can be measured as the ratio of foreign direct investment inflows to GDP or as the ratio of foreign direct investment to gross capital formation, the former would be adapted in this study because gross capital formation is also one of the variables to be used in the study.

Also, inspired by previous studies, especially the work of McKinnon (1973), Jeanneney and Kpodar (2008), financial openness has a positive impact on economic growth, which reduces poverty and that financial development has a direct and positive effect on the income of the poor. However, in countries experiencing financial instability, it could have a 
detrimental effect. The apriori relationship expected between financial openness and poverty is to be positive.

Therefore, a classical poverty model would be estimated as follows:

$$
P O V_{t}=\mu_{0}+\mu_{1} F O_{t}+\mu_{3} X_{t}+\varepsilon_{t}----------------(1)
$$

Where POV= Poverty

$\mathrm{X}=$ represents the control variables

$\mathrm{FO}=$ measure of financial openness

Poverty would be measured using the poverty headcount index, and it measures the percentage of the population living below a certain poverty line. Also, in estimating a classical poverty model, there are some common variables that used and they are, GDP per capita, a variable of financial deepening (Ratio of Private credit to GDP) or (Ratio of M2 to GDP), investment (Ratio of gross capital formation and GDP), Inflation to determine the macroeconomic stability and institutional quality (measures the strength and impartiality of the legal system and the popular observance of the law). This study would make use of aggregate secondary data gotten from World development indicator, International country risk guide (ICGR) database and CBN statistical bulletin from 1981 to 2018 .

The ARDL specification is shown below:

$$
\begin{aligned}
\triangle P O V_{t}=\alpha+ & \alpha_{1} \Delta P O V_{t-1}+\alpha_{2} \Delta F O P_{t} \\
& +\alpha_{3} \Delta G D P P C_{t}+\alpha_{4} \Delta F D P 1_{t} \\
& +\alpha_{5} \Delta I N V E S T_{t}+\alpha_{6} \Delta I N F L_{t} \\
& +\alpha_{7} \Delta I N S T I T_{t}+\mu_{t}
\end{aligned}
$$

\begin{tabular}{|c|c|c|c|c|c|c|}
\hline \multicolumn{7}{|c|}{ Descriptive Statistics } \\
\hline $\begin{array}{c}\text { Variabl } \\
\text { es }\end{array}$ & Mean & Median & Std.dev & $\begin{array}{c}\text { Skewne } \\
\text { ss }\end{array}$ & $\begin{array}{c}\text { Kurtosi } \\
\text { s }\end{array}$ & $\begin{array}{c}\text { Jarque- } \\
\text { Bera }\end{array}$ \\
\hline POV & $\begin{array}{c}24.0315 \\
8\end{array}$ & $\begin{array}{c}21.8000 \\
0\end{array}$ & $\begin{array}{c}3.82976 \\
3\end{array}$ & $\begin{array}{c}1.11041 \\
7\end{array}$ & $\begin{array}{c}2.42738 \\
0\end{array}$ & $\begin{array}{c}8.32832 \\
3\end{array}$ \\
\hline FOP & $\begin{array}{c}1.76053 \\
8 \\
\end{array}$ & $\begin{array}{c}1.62501 \\
2 \\
\end{array}$ & $\begin{array}{c}1.25332 \\
8 \\
\end{array}$ & $\begin{array}{c}1.32183 \\
6 \\
\end{array}$ & $\begin{array}{c}4.87712 \\
6 \\
\end{array}$ & $\begin{array}{c}16.6449 \\
6 \\
\end{array}$ \\
\hline GDPPC & $\begin{array}{c}0.54490 \\
1\end{array}$ & $\begin{array}{c}1.55372 \\
4\end{array}$ & $\begin{array}{c}5.39416 \\
0\end{array}$ & $\begin{array}{c}- \\
0.87788 \\
3\end{array}$ & $\begin{array}{c}4.60477 \\
9\end{array}$ & $\begin{array}{c}8.95854 \\
5\end{array}$ \\
\hline FDP1 & $\begin{array}{c}11.0568 \\
4 \\
\end{array}$ & $\begin{array}{c}8.20000 \\
0\end{array}$ & $\begin{array}{c}5.38403 \\
3 \\
\end{array}$ & $\begin{array}{c}0.87544 \\
7 \\
\end{array}$ & $\begin{array}{c}1.96604 \\
8 \\
\end{array}$ & $\begin{array}{c}6.54658 \\
7 \\
\end{array}$ \\
\hline FDP2 & $\begin{array}{c}14.2026 \\
3\end{array}$ & $\begin{array}{c}12.6950 \\
0\end{array}$ & $\begin{array}{c}3.93204 \\
6\end{array}$ & $\begin{array}{c}0.59872 \\
2\end{array}$ & $\begin{array}{c}1.82906 \\
6\end{array}$ & $\begin{array}{c}4.44118 \\
4\end{array}$ \\
\hline $\begin{array}{c}\text { INVES } \\
T\end{array}$ & $\begin{array}{c}36.1318 \\
3\end{array}$ & $\begin{array}{c}35.3675 \\
5\end{array}$ & $\begin{array}{c}19.9579 \\
7\end{array}$ & $\begin{array}{c}0.83688 \\
2\end{array}$ & $\begin{array}{c}3.60047 \\
1\end{array}$ & $\begin{array}{c}5.00657 \\
8\end{array}$ \\
\hline
\end{tabular}

Replacing the FDP1 with FDP2, we have;

$$
\begin{aligned}
\triangle P O V_{t}=\alpha_{1} \Delta & P O V_{t-1}+\alpha_{2} \Delta F O P_{t}+\alpha_{3} \Delta G D P P C_{t} \\
& +\alpha_{4} \Delta F D P 2_{t}+\alpha_{5} \Delta I N V E S T_{t} \\
& +\alpha_{6} \Delta I N F L_{t}+\alpha_{7} \Delta I N S T I T_{t}+\mu_{t}
\end{aligned}
$$

\section{EMPIRICAL RESULTS AND DISCUSSION}

Table 1: Descriptive Statistics

\begin{tabular}{|c|c|c|c|c|c|c|} 
INFL & 19.3210 & 12.5500 & 17.2563 & 1.74108 & 4.83154 & 24.5101 \\
& 5 & 0 & 1 & 6 & 8 & 5 \\
\hline \multirow{2}{*}{ INSTIT } & - & - & 0.46272 & 0.13328 & 1.46413 & 3.84739 \\
& 0.53986 & 0.73677 & 1 & 5 & 7 & 6 \\
\hline
\end{tabular}

Table 1, above contains descriptive statistics for the study. It can be observed that on the average, investment recorded the highest across the sample variable, followed closely by inflation, growth rate per capita, financial deepening, poverty, financial openness and lastly institutional quality. From all indications, institutional quality with an index point of 0.462 is the least volatile when compared to other selected variables. Also, all the variables are positively skewed with the exception of GDPPC that is negatively skewed.

Kurtosis gives information about the degree of peakness of distributions and provides information about the sample. A normally distributed series is expected to have a kurtosis of 3.0 and the sample is mesokurtic (flat-topped distribution). if the value is greater than 3.0, the sample is leptokurtic (relatively high peak distribution) and if the value is less than 3.0, the series is platykurtic (relatively flat-topped distribution). From table 1, 50\% of the variables have leptokurtic distribution series and $50 \%$ also have platykurtic distribution series. Also, all the variables are positively skewed with the exception of GDPPC.

\section{Unit Root Test}

Table 2 below shows the unit root test and this is done to detect the presence and form of non-stationarity and the unit root property requires all variables to be stationary in levels or at first differences. The test for this property was conducted using the Augmented Dickey Fuller test. The table showed that the variables were integrated of order one I(1), that is stationary at first difference with the exception of Growth per capita which was integrated at levels $\mathrm{I}(0)$. If the variables are not stationary at the same order, OLS would not be used because it would bring about spurious results. The ARDL framework does not require pre-testing of variables, however, the unit root would convince us whether or not to use ARDL model.

Table 2

\begin{tabular}{|c|c|c|c|c|}
\hline \multicolumn{6}{|c|}{ Unit Root Tests Results } \\
\hline Variables & $\begin{array}{c}\text { ADF } \\
\text { Statistics }\end{array}$ & $\begin{array}{c}\text { Critical value } \\
@ 5 \%\end{array}$ & Probability & Remarks \\
\hline POV & -5.831 & -2.946 & 0 & $\mathrm{I}(1)$ \\
\hline FOP & -8.406 & -2.943 & 0 & $\mathrm{I}(1)$ \\
\hline GDPPC & -4.131 & -2.945 & 0.00261 & $\mathrm{I}(0)$ \\
\hline FDP1 & -4.845 & -2.946 & 0.0004 & $\mathrm{I}(1)$ \\
\hline FDP2 & -5.637 & -2.945 & 0 & $\mathrm{I}(1)$ \\
\hline INVEST & -4.618 & -2.946 & 0.0007 & $\mathrm{I}(1)$ \\
\hline INFL & -5.592 & -2.945 & 0 & $\mathrm{I}(1)$ \\
\hline INSTIT & -6.355 & -2.945 & 0 & $\mathrm{I}(1)$ \\
\hline Source: Authorscomputation \\
\hline
\end{tabular}


Table 3: Correlation Analysis

\begin{tabular}{|c|c|c|c|c|c|c|c|c|}
\hline \multicolumn{9}{|c|}{ Correlation Analysis } \\
\hline Variables & POV & FOP & GDPPC & FDP1 & FDP2 & INVEST & INFL & INSTIT \\
\hline POV & 1 & & & & & & & \\
\hline FOP & $0.393 *$ & 1 & & & & & & \\
\hline GDPPC & 0.111 & 0.128 & 1 & & & & & \\
\hline FDP1 & -0.354 & $\begin{array}{c}- \\
0.116\end{array}$ & 0.183 & 1 & & & & \\
\hline FDP2 & -0.334 & $\begin{array}{c}- \\
0.081\end{array}$ & 0.241 & 0.955 & 1 & & & \\
\hline INVEST & -0.976 & $\begin{array}{c}- \\
0.133\end{array}$ & -0.615 & $\begin{array}{c}- \\
0 . \overline{7} 22\end{array}$ & $\begin{array}{c}- \\
0.762\end{array}$ & 1 & & \\
\hline INFL & 0.191 & 0.537 & -0.217 & $\begin{array}{c}- \\
0.287 \\
\end{array}$ & $\begin{array}{c}- \\
0.28)\end{array}$ & 0.197 & 1 & \\
\hline INSTIT & -0.257 & $\overline{0 .} \overline{018}$ & -0.501 & $0 . \overline{404}$ & $\begin{array}{c}- \\
0.453\end{array}$ & 0.702 & 0.467 & 1 \\
\hline & $\begin{array}{l}\text { e: Autho } \\
\text { iputation }\end{array}$ & & & & & & & \\
\hline
\end{tabular}

Table 3 above shows the correlation matrix and it presents the degree of correlation between the explained and the explanatory variables. The matrix reflects that most of the variables have weak correlation while very few of the variables exhibit strong correlations. The variables can be seen to be in good fit as the rule of correlation which states variables should not have a correlation of $80 \%$ was satisfied.

Table 4: Lag order Selection Criteria Results

\begin{tabular}{|c|c|c|c|c|c|c|}
\hline VAR Lag Order Selection Criteria & & & & & \\
\hline Lag & LogL & LR & FPE & AIC & SC & HQ \\
\hline 0 & -85.98406 & NA & 12.6906 & 5.370518 & 5.726026 & 5.493239 \\
\hline 1 & -69.25678 & $24.85196^{*}$ & $5.184879 *$ & $4.471816^{*}$ & $4.871763^{*}$ & $4.609878^{*}$ \\
\hline 2 & -69.25643 & 0.000501 & 5.514716 & 4.528939 & 4.973324 & 4.682341 \\
\hline 3 & -69.04791 & 0.285974 & 5.802596 & 4.574166 & 5.06299 & 4.742908 \\
\hline * indicates lag order selected by the criterion & & & & \\
\hline LR: sequential modified LR test statistic (each test at 5\% level) & & & \\
\hline FPE: Final prediction error & & & \\
\hline AIC: Akaike information criterion & & & \\
\hline SC: Schwarz information criterion \\
\hline HQ: Hannan-Quinn information criterion \\
\hline Source: Authors Computation
\end{tabular}

From Table 4 above, before we run the ARDL, we have to find the optimal lag selection that would be used in the analysis. The Akaike Information Criterion (AIC), Schwartz Bayesian information Criteria (SIC) and the Hannan-Quinn information criterion (HQ) are identified in literature as appropriate in selecting optimal lag lengths. From the table above, it can be seen that all the methods chose a one lag period and that is what is going to be used during the ARDL specification.
Table 5: Bounds Test Cointegration Results

\begin{tabular}{|c|c|c|c|c|c|c|}
\hline \multicolumn{3}{|c|}{ ARDL Bounds Test } & & & & \\
\hline \multicolumn{5}{|c|}{ Null Hypothesis: No long run relationship exists } & & \\
\hline T-stat & Value & Lag & $\begin{array}{l}\text { Signi } \\
\text { level }\end{array}$ & $\begin{array}{c}\text { Bound Critical } \\
\text { Values }\end{array}$ & & \\
\hline \multirow[t]{5}{*}{$\begin{array}{c}\text { F- } \\
\text { statistics } \\
\end{array}$} & $\begin{array}{c}1.650 \\
8\end{array}$ & 1 & & $\mathrm{I}(0)$ & $\mathrm{I}(1)$ & $\mathrm{K}=6$ \\
\hline & & & $1 \%$ & 3.15 & 4.43 & \\
\hline & & & $2.50 \%$ & 2.75 & 3.99 & \\
\hline & & & $5 \%$ & 2.45 & 3.61 & \\
\hline & & & $10 \%$ & 2.12 & 3.23 & \\
\hline \multicolumn{4}{|c|}{ Source: Authors Computation } & & & \\
\hline
\end{tabular}


The table above shows the bound test results. Due to the fact that the Johannsen cointegration procedure would not be possible, the ARDL bound test approach which was proposed by Pesaran et al (2001) would be able to ascertain if a long run equilibrium relationship exist among the variables in the model since it's a combination of $\mathrm{I}(0)$ and $\mathrm{I}(1)$ order. In the table above, the bounds cointegration test demonstrates that the computed F-statistic of 1.6508 is less than the critical bound value of 2.12 at the $10 \%$ level. Thus, the null hypothesis is easily accepted, indicating no existence of a steady state long run relationship among the variable.

\section{ARDL Results}

In this section, we are going to have to results of ARDL. This is because we want to find out using the two indicators of financial deepening separately whether there would be any significant change in the result.

Table 6a ARDL Result

\begin{tabular}{|c|c|c|c|}
\hline \multicolumn{4}{|c|}{$\begin{array}{c}\text { Dependent Variable } \\
\text { (POV) }\end{array}$} \\
\hline Variables & Coefficient & T-statistics & Probability \\
\hline POV(-1) & 0.78119 & 7.570586 & $0^{*}$ \\
\hline FOP & 0.789772 & 2.06283 & $0.0497^{*}$ \\
\hline GDPPC & 0.062008 & 0.750554 & 0.4599 \\
\hline GDPPC(-1) & -0.358118 & -3.673758 & $0.0011^{*}$ \\
\hline FDP1 & -0.267489 & -2.256933 & $0.033^{*}$ \\
\hline INVEST & 0.028017 & 0.422336 & 0.6764 \\
\hline INVEST(-1) & -0.144841 & -1.86847 & $0.0735^{*}$ \\
\hline INFL & -0.004035 & -0.157581 & 0.8761 \\
\hline INFL(-1) & -0.07187 & -2.346036 & $0.0272^{*}$ \\
\hline INSTIT & -2.394716 & -1.344733 & 0.1908 \\
\hline INSTIT(-1) & 4.631308 & 2.656349 & $0.0136^{*}$ \\
\hline C & 14.01268 & 3.092922 & $0.0048^{*}$ \\
\hline R- Squared & 0.878 & & \\
\hline $\begin{array}{c}\text { Adjusted R } \\
\text { F-statistic }\end{array}$ & 0.825 & & \\
prob(F-statistic) & 16.44594 & & \\
Durbin Watson & 1.726 & & \\
\hline
\end{tabular}

*indicates $1 \%$ level of significance

From the table above, we found that the lagged value of poverty has a positive and significant relationship with itself. This just buttresses the point that poverty in the previous period filters directly into the present period. Also, financial openness is seen to have a positive and significant impact on poverty and this follows the study of (Dhrifi and Maktouf, 2013; Okungbowa et al, 2014; Lassoued, 2018) who found that an increase in financial openness in an economy has led to a decline in poverty.

However, financial deepening has a negative and significant effect on poverty, which supports the opinion of McKinnon and Shaw (1973). The lagged value of growth rate, investment, inflation and institutional quality has a negative and significant effect on poverty.

Table 6b: ARDL Results

$\left.\begin{array}{|c|c|c|c|}\hline \multicolumn{4}{|c|}{\text { Dependent Variable (POV) }} \\ \hline \text { Variables } & \text { Coefficient } & \text { T-statistics } & \text { Probability } \\ \hline \text { POV(-1) } & 0.773186 & 8.080976 & 0^{*} \\ \hline \text { FOP } & 0.992957 & 2.66929 & 0.0132^{*} \\ \hline \text { GDPPC } & 0.056793 & 0.739747 & 0.4663 \\ \hline \text { GDPPC(-1) } & -0.335156 & -3.882898 & 0.0007^{*} \\ \hline \text { FDP2 } & -0.449215 & -2.993069 & 0.0061^{*} \\ \hline \text { INVEST } & -0.017188 & -0.266705 & 0.7919 \\ \hline \text { INVEST(-1) } & -0.109733 & -1.660447 & 0.1093 \\ \hline \text { INFL } & -0.002104 & -0.088314 & 0.9303 \\ \hline \text { INFL(-1) } & -0.093694 & -3.018006 & 0.0058 \\ \hline \text { INSTIT } & -2.840784 & -1.691756 & 0.1031 \\ \hline \text { INSTIT(-1) } & 5.142221 & 3.08876 & 0.0049^{*} \\ \hline \text { C } & 17.94605 & 3.766308 & 0.0009^{*} \\ \hline \begin{array}{c}\text { R- Squared } \\ \text { Adjusted R }\end{array} & 0.892 & & \\ \text { F-statistic } \\ \text { prob(F-statistic) } \\ \text { Durbin Watson }\end{array}\right)$

*indicates $1 \%$ level of significance

Also, from table $6 \mathrm{~b}$ above, the study found that the lagged value of poverty has a positive and significant relationship with itself and this buttresses the point that poverty in the previous period filters directly into the present period. Also, financial openness is seen to have a positive and significant impact on poverty. Financial deepening has a negative and significant effect on poverty, the results supports the opinion of McKinnon and Shaw (1973). The lagged value of growth rate, investment, inflation and institutional quality has a negative and significant effect on poverty and lastly, investment in the current period has a positive and significant relationship with poverty.

In summary, from table $6 \mathrm{a}$ and $6 \mathrm{~b}$ above, there is no significant difference in the result when using ratio of credit to the private sector and GDP as financial deepening 1 and when using the ratio of money supply to GDP as financial deepening 2 . The only difference observed is that investment in the current period has a positive effect on poverty when the financial deepening 2 is used.

\section{Serial correlation}

After testing the ARDL model, it is of necessity to test for serial correlation among the variables. From table 7 below, the $\mathrm{P}$ value associated with the chi-square is way more than $5 \%$, 
so we cannot reject the null hypothesis. The result shows no evidence of serial correlation.

Table 7: Stability Test Results

\begin{tabular}{|c|c|c|c|}
\hline \multicolumn{4}{|c|}{ Breusch-Godfrey Serial Correlation LM Test: } \\
\hline F-statistic & 0.750247 & Prob. F(1,24) & 0.395 \\
\hline Obs*R-squared & 1.12157 & Prob. Chi-Square(1) & 0.2896 \\
\hline
\end{tabular}

\section{CONCLUSION}

The paper studied the effect of financial openness on poverty reduction in Nigeria and to see if there exist a long run relationship between financial openness and poverty. The result of the ARDL estimates showed that poverty in previous periods has significant effect on the poverty levels in recent periods. Also, financial openness is seen to have a positive effect in reducing poverty in the Nigerian economy, while financial deepening has a negative and significant effect on poverty, which supports the opinion of McKinnon and Shaw (1973). Th study also found that growth rate, investment, inflation and institutional quality has a negative and significant effect on poverty. Also, the ARDL bound test approach used to test the long run relationship between the variables shows that there is no existence of a steady state long run relationship among the variable. Thus, our findings show that the more financial openness in Nigeria is capable of reducing poverty in the country. Thus, it would be recommended that government should undertake policy reforms that are targeted at a better financial sector that would enhance the reduction of poverty in Nigeria. The government should generally provide easy access to funds, good environment for doing business and improve the institutional quality in the country.

\section{REFERENCES}

[1] Adam, A.M (2011). Financial openness induced growth and poverty reduction. The International journal of Applied Economics and Finance, 5 (1), 75-86.

[2] Agenor P.R (2002). Does Globalization hurt the poor? The World Bank Policy Research Working Paper 2922.

[3] Ajide, F. (2015). Financial inclusion and rural poverty reduction: Evidence from Nigeria. International journal of management sciences and humanities, 3(2).

[4] Arestis, P. \& Caner, A (2005). Financial liberalization and poverty: Channels of influence. Palgrave Macmillian, a division of Macmillian Publishers Limited.

[5] Arestis, P. \& Caner, A. (2009). Financial liberalization and the geography of poverty. Cambridge journal of Regions, Economy and society Advance, 43, 1-16.
[6] CBN Annual Statistical Bulletin (2018)

[7] Dandume M.Y \& Malarvizhi A.C. (2014). Does financial liberalization spur economic growth and poverty reduction in six Sub-Saharan African countries; Panel unit root and panel vector error correction tests. Munich Personal RePEc Archive (MPRA), 52419

[8] DFID (2004). The importance of financial sector development for growth and poverty reduction: Policy Division Working Paper, Department for international development, London, UK.

[9] Dhrifi, A \& Maktouf, S. (2013). Financial liberalization and poverty: The Threshold effect of financial development. International journal of business and management invention, 2(11), 01-10.

[10] Figini, P. \& Santarelli, E. (2006). Openness, Economic reforms and Poverty: Globalization in developing countries. The journal of Developing Areas, 39(2).

[11] Galindo, A., Micco, A., \& Ordonez, G. (2002). Financial liberalization and growth: Empirical Evidence. Inter-American Development Bank.

[12] Goff, M. \& Singh, R. (2012). Does Trade reduce Poverty? A view from Africa center for the conference, march 18-20, 2012. study of African economies

3] Jeanneney, S.G \& Kpodar, K. (2008). Financial development and poverty reduction: Can there be a benefit without a cost? International monetary fund (IMF), 8 (62).

[14] Keho, Y. (2017). Financial development and poverty reduction: Evidence from selected African countries. International journal of financial research, 8(4).

[15] Lassoued, T. (2018). The effect of financial liberalization and inflation on poverty. International Research Journal of finance and Economics, 170, 77-91.

[16] McKinnon, R.I. (1973). Money and Capital in Economic Development. 1st Edn., Brookings Institution, Washington DC., USA., ISBN-10: 0815756135, 177.

[17] Ogbuaku, H.N., Adebisi, A., \& Feridun, M. (2006). Does globalization lead to increased poverty in africa? Empirical Evidence from Nigeria. International Economics, camera di commercio industria Artigianato Agricoltura di Geneva, 59(1).

[18] Ogwuma, P.A. (1993). Recent Developments in the Nigerian Financial Services Industry: Problems and Challenges. An Address at Annual Dinner of the Chartered Institute of Bankers of Nigeria, Lagos.

[19] Ojo, M.O. (1993). A review and appraisal of Nigerias experience with financial sector reform. Occasional Paper $8(C B N)$, August, Lagos.

[20] Okungbowa, F.O., Ewerere, E., \& Ose, C. (2014). Globalization and poverty rate in nigeria: An empirical Analysis. International journal of humanities and social science, 4(11).

[21] Serdaroglu, T. (2015). Financial Openness and Total factor productivity in Turkey. Procedia Economics and Finance, 30, 848-862

[22] Shaw, E.S. (1973). Financial Deepening in Economic Development. Oxford University Press, New York, USA. 39.

[23] Townsend .P. (1979). Poverty in the United Kingdom. Harmondsworth Penguin.

[24] World Bank Development Indicator (2018) 